\title{
Self-Organizing Map Menggunakan Davies-Bouldin Index dalam Pengelompokan Wilayah Indonesia Berdasarkan Konsumsi Pangan
}

\author{
Mujiati Dwi Kartikasari* \\ Program Studi Statistika, Fakultas MIPA, Universitas Islam Indonesia, \\ Jl. Kaliurang Km. 14,5 Yogyakarta, Indonesia \\ * Penulis Korespondensi. Email: mujiatikartikasari@uii.ac.id
}

\begin{abstract}
ABSTRAK
Kecukupan konsumsi pangan merupakan salah satu penunjang terbentuknya sumber daya manusia unggul yang menjadi fokus kebijakan pembangunan di Indonesia. Agar konsumsi pangan terpenuhi, salah satu cara yang dapat dilakukan adalah melakukan pengelompokan wilayah berdasarkan konsumsi pangan. Penelitian ini bertujuan untuk mengelompokkan wilayah Indonesia berdasarkan konsumsi pangan berdasarkan data konsumsi kalori per kapita sehari dari berbagai komoditas pangan. Pengelompokan wilayah dilakukan dengan metode self-organizing map (SOM) dengan terlebih dahulu ditentukan jumlah cluster optimum menggunakan nilai Davies-Bouldin Index (DBI) terkecil. Hasil penelitian menunjukkan bahwa hasil cluster optimum yang terbentuk sejumlah 4 cluster dengan jumlah anggota untuk cluster 1 sebanyak 22 provinsi, cluster 2 sebanyak 10 provinsi, cluster 3 sebanyak 1 provinsi, dan cluster 4 sebanyak 1 provinsi.
\end{abstract}

Kata Kunci:

Konsumsi Pangan; Cluster; Pengelompokan Wilayah; Self-Organizing Map; Davies-Bouldin Index

ABSTRACT

Adequate food consumption is one of the supports for forming superior human resources, which is the focus of development policies in Indonesia. To fulfill food consumption, one way to be done is to group regions based on food consumption. This study aims to classify regions of Indonesia based on food consumption based on average daily per capita calorie consumption data from various food commodities. Regional grouping is done using the self-organizing map (SOM) method by first determining the optimum number of clusters using the smallest Davies-Bouldin Index (DBI) value. The results showed that the optimum cluster results were 4 clusters with the number of members for cluster 1 as many as 22 provinces, cluster 2 as many as 10 provinces, cluster 3 as many as 1 province, and cluster 4 as many as 1 province.

Keywords:

Food Consumption; Cluster; Regional Grouping; Self-Organizing Map, Davies-Bouldin Index

Format Sitasi:

M. D. Kartikasari, "Self-Organizing Map Menggunakan Davies-Bouldin Index dalam Pengelompokan Wilayah Indonesia Berdasarkan Konsumsi Pangan," Jambura J. Math., vol. 3, no. 2, pp.187-196, 2021

e-ISSN: 2656-1344 (C) 2021 M. D. Kartikasari | Under the license CC BY-NC 4.0

Received: 15 June 2021 | Accepted: 7 July 2021 | Online: 10 July 2021 


\section{Pendahuluan}

Kebijakan pembangunan di Indonesia salah satunya difokuskan pada peningkatan kualitas sumber daya manusia [1]. Sumber daya manusia yang unggul sangat ditentukan oleh kecukupan asupan gizi yang diperoleh dari konsumsi pangan yang baik. Konsumsi pangan berkualitas tidak hanya dinilai dari sisi jumlah, namun juga dari sisi mutu, kandungan gizi, keberagaman jenis, serta jaminan keamanannya. Kurangnya konsumsi pangan dapat menyebabkan kelaparan yang dapat berimbas buruk pada menurunnya kualitas sumber daya manusia. Menurut data dari Global Hunger Index (GHI) [2], Indonesia memiliki indeks kelaparan di tahun 2020 sebesar 19,10 dengan kategori moderat [2]. Nilai indeks ini cukup mengkhawatirkan karena hanya selisih 0,90 poin dari kategori tingkat kelaparan serius $(20,00-34,90)$. Melalui program Sustainable Development Goals (SDGs), Indonesia berkomitmen untuk mengakhiri kelaparan dengan menciptakan ketahanan pangan yang baik. Sebagai negara dengan wilayah yang luas dan penduduk yang besar, ketahanan pangan menjadi tantangan yang sangat kompleks dan menjadi agenda serius yang harus ditangani karena menyangkut kualitas sumber daya manusia.

Ketahanan pangan terdiri dari beberapa aspek, diantaranya adalah ketersediaan pangan, aksesibilitas (keterjangkauan), dan pemanfaatan pangan [3]. Salah satu upaya untuk mendukung terciptanya ketahanan pangan yang baik di Indonesia adalah dengan melakukan pengelompokan wilayah berdasarkan konsumsi pangan. Hal ini dimaksudkan untuk dapat meningkatkan konsumsi pangan dengan kuantitas dan kualitas yang baik sehingga asupan gizi terpenuhi serta kekhawatiran tentang kelaparan teratasi. Lebih jauh, pengelompokan wilayah berdasarkan konsumsi pangan dapat mendukung peningkatan kualitas sumber daya manusia sebagai generasi penerus calon pemimpin bangsa.

Pengelompokan wilayah berdasarkan konsumsi pangan dapat dilakukan dengan metode statistika, yaitu menggunakan analisis cluster. Analisis cluster adalah proses pengelompokan sekumpulan objek data menjadi beberapa cluster sehingga objek dalam suatu cluster memiliki kemiripan yang tinggi, tetapi sangat berbeda dengan objek di cluster lain [4]. Terdapat banyak jenis analisis cluster, diantaranya adalah hierarchical clustering, neural network-based clustering, kernel-based clustering, dan sequential data clustering [5]. Karena memiliki keunggulan berupa kemampuan belajar yang baik, kemampuan adaptasi, kemudahan impelentasi, kecepatan, dan fleksibilitas, teknik neural network banyak diterapkan untuk memecahkan berbagai masalah, termasuk penggunaannya dalam analisis cluster. Analisis cluster yang paling populer dari teknik neural network adalah self-organizing map (SOM) [6]. SOM memiliki metode pembelajaran mandiri (unsupervised learning) dimana proses pembelajaran yang dilakukan tanpa pengawasan [7]. SOM mampu memberikan visualisasi yang efisien dan pemahaman yang mudah dengan mengubah data dimensi tinggi menjadi peta dua dimensi [8].

Langkah pertama dalam analisis cluster menggunakan SOM adalah menentukan jumlah cluster. Dalam menentukan jumlah cluster, diperlukan validitas cluster. Validitas cluster ini bertujuan untuk mengetahui apakah jumlah cluster yang terbentuk optimum atau tidak. Salah satu indeks validitas yang dapat digunakan untuk menentukan apakah jumlah cluster optimum adalah Davies-Bouldin Index (DBI) [9].

SOM telah banyak diimplementasikan untuk memodelkan berbagai masalah, seperti perencanaan produksi perusahaan [10], pemodelan kualitas air dalam pengolahan air 
minum [11], pemetaan kekeringan akibat global warming [12], pengelompokan negara di dunia berdasarkan data kasus Covid-19 [13], dan lain sebagainya. Impementasi SOM dapat secara efektif memberikan solusi terkait strategi untuk pemerataan konsumsi pangan. Model yang dibangun digunakan untuk menghasilkan peta sebaran pangan di Indonesia. Metode SOM yang diadopsi pada penelitian ini adalah untuk mengetahui kecukupan pangan di Indonesia berdasarkan data rata-rata konsumsi kalori per kapita sehari. Tujuan dari penelitian ini adalah memberikan informasi awal terkait dengan sebaran wilayah di Indonesia berdasarkan kecukupan pangan yang baik.

\section{Metode}

Penelitian ini terdiri dari beberapa tahapan. Pertama, penelitian diawali dengan mendeskripsikan data untuk mengetahui gambaran umum dari data yang digunakan. Kemudian, dilanjutkan dengan menentukan jumlah cluster optimum menggunakan DBI. Setelah jumlah cluster optimum diperoleh, lalu dilakukan analisis cluster dengan metode SOM. Analisis SOM digunakan untuk mengelompokkan provinsi-provinsi di Indonesia dengan karakteristik data yang sama masuk dalam cluster tertentu. Proses penelitian diakhiri dengan profilisasi cluster untuk mengetahui kriteria spesifik dari setiap cluster yang terbentuk. Gambar 1 menunjukkan tahapan penelitian dalam sebuah flowchart.

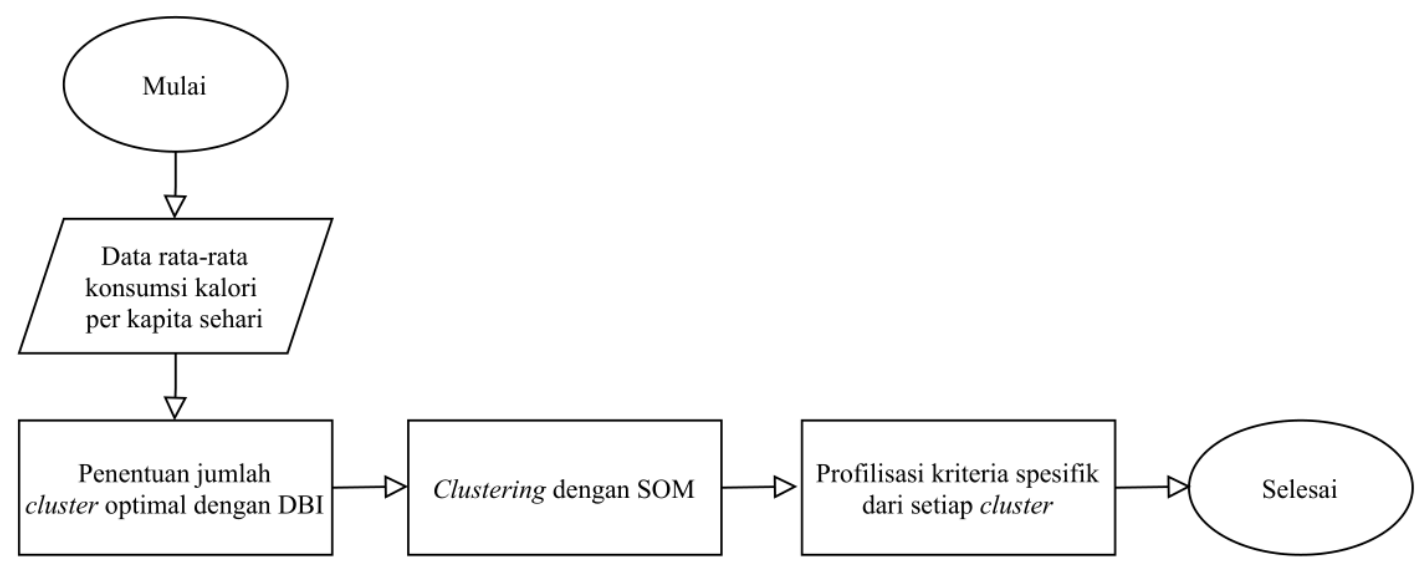

Gambar 1. Tahapan penelitian

\subsection{Davies-Bouldin Index}

Davies-Bouldin Index (DBI) adalah rasio dari jumlah jarak intra-cluster dan jarak intercluster [14]. Untuk mencapai hasil clustering yang baik, jarak inter-cluster harus tinggi dan jarak intra-cluster harus rendah dan oleh karena itu, nilai DBI yang lebih rendah diperlukan agar menunjukkan hasil clustering yang baik.

Langkah-langkah dalam menghitung DBI adalah sebagai berikut [15]:

1. Menghitung jarak intra-cluster sebagai standar deviasi antara setiap titik data dalam cluster dengan pusat cluster,

$$
S_{i}=\left\{\frac{1}{T_{i}} \sum_{j=1}^{T_{i}}\left|X_{j}-A_{i}\right|^{2}\right\}^{\frac{1}{2}},
$$


dengan $T_{i}$ adalah banyaknya data pada cluster $i, X_{j}$ adalah vektor pada cluster $i$, dan $A_{i}$ adalah pusat cluster $i$.

2. Menghitung jarak inter-cluster sebagai jarak setiap pasangan cluster,

$$
M_{i j}=\left\|a_{i}-a_{j}\right\|^{2}
$$

dengan $a_{i}$ adalah pusat cluster $i$ dan $a_{j}$ adalah pusat $c l u s t e r ~ j$, untuk $i \neq j$.

3. Untuk setiap pasangan cluster, sebaran clusternya ditambahkan dan kemudian totalnya dibagi dengan jarak antara kedua cluster,

$$
R_{i j}=\frac{S_{i}+S_{j}}{M_{i j}}
$$

sebagai ukuran kesamaan cluster yang merepresentasikan kebaikan dari clustering antara kedua cluster tersebut.

4. Menghitung ukuran kesamaan cluster maksimum,

$$
R_{i}=\max _{i \neq j} R_{i j}
$$

5. Menghitung DBI sebagai rata-rata ukuran kesamaan cluster maksimum,

$$
D B I=\frac{1}{K} \sum_{i=i}^{K} R_{i}
$$

dengan $K$ adalah banyaknya cluster.

\subsection{Self-Organizing Map}

Self-organizing map (SOM) pertama kali diperkenalkan oleh Teuvo Kohonen pada tahun 1982 [16]. SOM merupakan metode analisis data yang digunakan secara luas untuk analisis cluster dan visualisasi, yang terdiri dari kata "Self-Organizing" dan "Map". Kata "Self-Organizing" diberikan karena pada metode ini tidak diperlukan pengawasan dalam proses pembelajaran, dan kata "Map" diberikan karena pada metode ini dilakukan pemetaan bobot agar sesuai dengan data input yang diberikan [14].

SOM memiliki sejumlah keunggulan, diantaranya: (1) SOM tidak memerlukan asumsi tentang distribusi variabel dan juga tidak memerlukan independensi di antara variabel, (2) SOM lebih mudah diimplementasikan dan mampu memecahkan masalah nonlinier dengan kompleksitas sangat tinggi, (3) SOM efektif dalam menangani data noise dan data missing, berdimensi sangat kecil, serta sampel dengan ukuran tidak terbatas [17].

Dalam algoritma SOM, dimisalkan sekumpulan field $m$ untuk setiap record ke- $n$ sebagai vektor input $\mathbf{x}_{n}=x_{n 1}, x_{n 2}, \cdots x_{n m}$, dan dimisalkan sekumpulan bobot $m$ untuk setiap node output $j$ sebagai vektor bobot $\mathbf{w}_{j}=w_{1 j}, w_{2 j}, \cdots w_{m j}$ [18]. Untuk setiap vektor input $\mathbf{x}$, lakukan [18]:

1. Kompetisi. Untuk setiap node output $j$, hitung nilai $D\left(w_{j}, x_{n}\right)$ yang merupakan fungsi jarak Eucledian, yang didefinisikan sebagai berikut: 
Self-Organizing Map Menggunakan Davies-Bouldin Index dalam Pengelompokan ...

$$
D\left(w_{j}, x_{n}\right)=\sqrt{\sum_{i}\left(w_{i j}-x_{n i}\right)^{2}} .
$$

Temukan nilai jarak yang paling minimum sebagai node pemenang $J$.

2. Kooperasi. Identifikasi semua node output $j$ dalam lingkungan node pemenang $J$ yang didefinisikan oleh lingkungan berukuran $R$. Untuk node tersebut, lakukan:

Adaptasi. Perbaharui nilai bobot:

$$
w_{i j, \text { new }}=w_{i j, \text { current }}+\eta\left(x_{n i}-w_{i j, \text { current }}\right),
$$

dengan $\eta$ adalah learning rate dan $0<\eta<1$.

3. Perbaharui learning rate dan ukuran lingkungan $R$, seperlunya.

4. Hentikan perlakuan ketika kriteria pemberhentian terpenuhi.

\section{Hasil dan Pembahasan}

Berdasarkan tujuan penelitian yaitu melakukan profilisasi wilayah Indonesia berdasarkan konsumsi pangan, peneliti menggunakan data rata-rata konsumsi kalori per kapita sehari pada bulan Maret 2020 di seluruh provinsi di Indonesia menurut kelompok komoditas (kkal), seperti padi-padian, umbi-umbian, ikan, daging, telur dan susu, kacang-kacangan, buah-buahan, minyak dan kelapa, bumbu-bumbuan, konsumsi lainnya, serta makanan dan minuman jadi [19] yang disajikan pada Gambar 2.

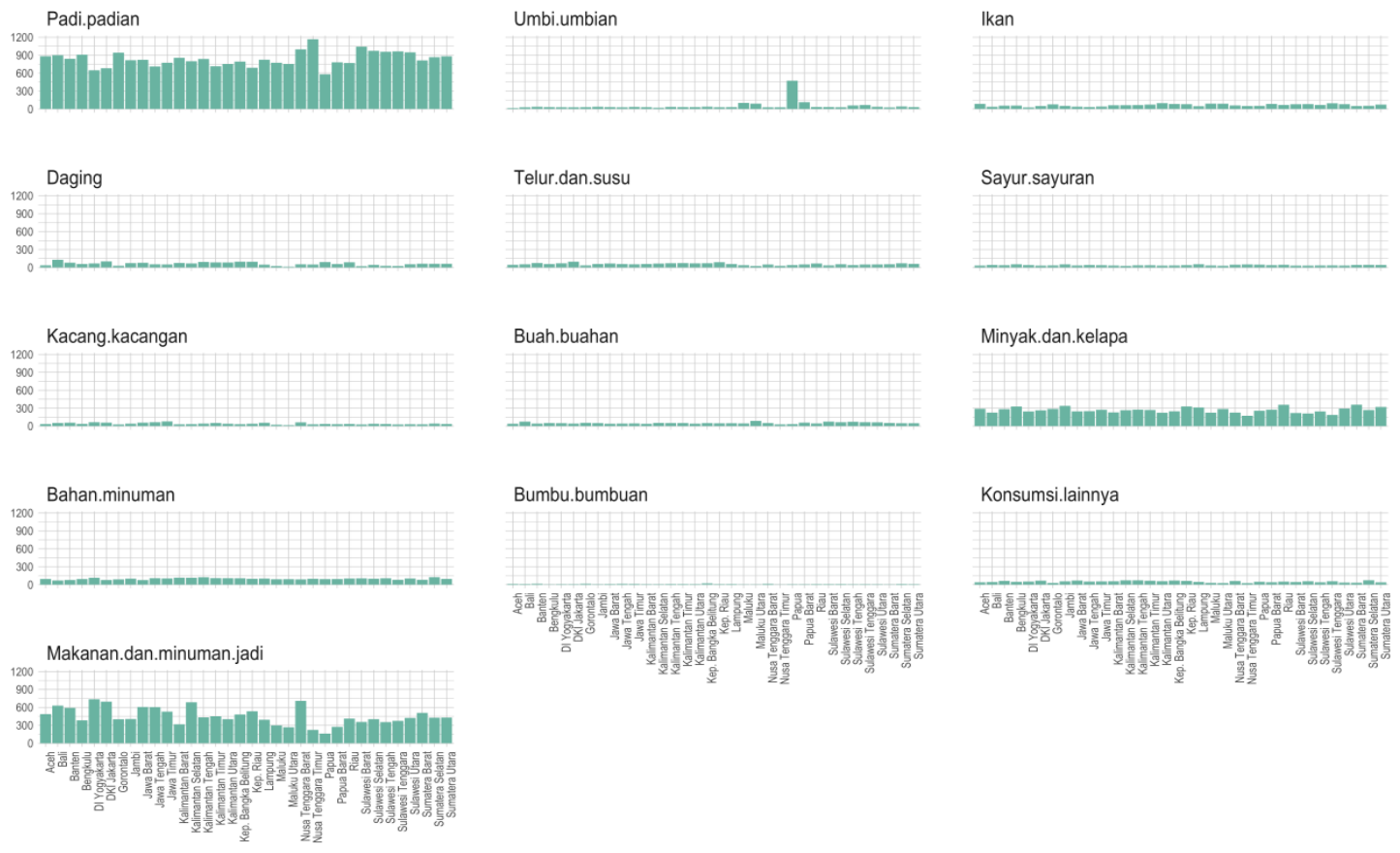

Gambar 2. Data rata rata-rata konsumsi kalori per kapita sehari menurut kelompok komoditas (kkal) di seluruh provinsi di Indonesia

Gambar 2 menunjukkan bahwa konsumsi kalori per kapita sehari terbesar di seluruh Provinsi Indonesia berasal dari komoditas padi-padian, makanan dan minuman jadi, 
serta minyak dan kelapa. Provinsi dengan konsumsi kalori dari komoditas padi-padian paling tinggi adalah Provinsi Nusa Tenggara Timur $(1166,22 \mathrm{kkal})$ dan paling rendah adalah Provinsi Papua (579,34 kkal). Konsumsi kalori dari komoditas makanan dan minuman jadi, paling tinggi adalah Provinsi DI Yogyakarta $(736,21 \mathrm{kkal})$ dan paling rendah adalah Provinsi Papua (161,17 kkal). Provinsi dengan konsumsi kalori dari komoditas minyak dan kelapa paling tinggi adalah Provinsi Sumatera Barat $(357,22$ kkal) dan paling rendah adalah Provinsi Nusa Tenggara Timur (172,72 kkal). Adapun konsumsi kalori per kapita sehari dari komoditas lain relatif lebih kecil dibandingkan dengan komoditas padi-padian, makanan dan minuman jadi, serta minyak dan kelapa.

Konsumsi kalori tersebar di seluruh provinsi di Indonesia. Identifikasi karakteristik provinsi di Indonesia berdasarkan konsumsi kalori per kapita dilakukan untuk mengelompokkan provinsi-provinsi tersebut ke dalam cluster tertentu. Pengelompokan provinsi dilakukan menggunakan SOM. Sebelum dilakukan analisis SOM, terlebih dahulu ditentukan jumlah cluster optimum dengan menggunakan DBI.

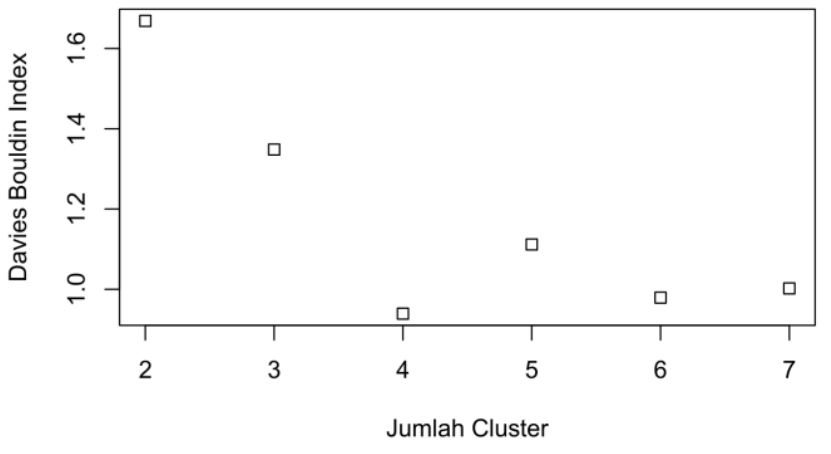

Gambar 3. Davies-Bouldin Index

Gambar 3 menunjukkan nilai DBI untuk 2 cluster sampai dengan 7 cluster. Nilai DBI yang baik adalah nilai yang paling kecil. Pada Gambar 3, nilai DBI yang paling kecil yaitu untuk 4 cluster. Dengan demikian, jumlah cluster optimum diperoleh sejumlah 4 cluster.

Setelah ditentukan jumlah cluster optimum, selanjutnya dilakukan analisis dengan SOM. SOM dilatih secara iteratif melalui sejumlah iterasi. Iterasi akan berhenti ketika keanggotaan dalam cluster tidak lagi mengalami perubahan atau konvergen. Pada penelitian ini pelatihan dilakukan sampai dengan 1.000 iterasi. Hasil iterasi dapat dilihat pada progres pelatihan yang disajikan pada Gambar 4 .

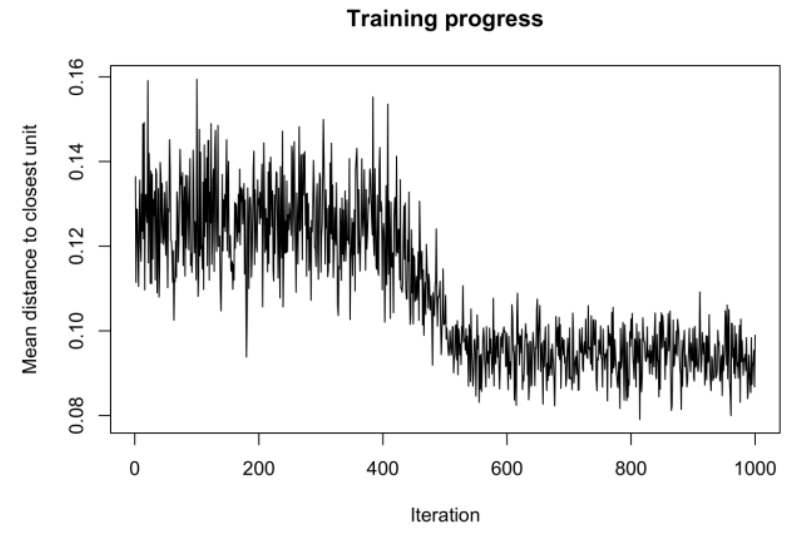

Gambar 4. Progres pelatihan 
Gambar 4 menjelaskan progres pelatihan yang menunjukkan jumlah iterasi. Progress pelatihan atau iterasi digunakan untuk mengetahui seberapa besar waktu yang dibutuhkan agar cluster menjadi optimal, semakin banyak iterasi yang dilakukan maka jarak intra-cluster semakin kecil dan hasil pengelompokan akan semakin baik. Setelah melewati kurang lebih 600 iterasi, dapat dilihat bahwa kemajuan pelatihan mulai stabil dengan rata-rata jarak intra-cluster di bawah 0,1.

Pengelompokan menggunakan metode SOM berkonsetrasi pada kesamaan intra-cluster terbesar. Tingkat kesamaan tersebut diketahui berdasarkan jaraknya. Semakin kecil jarak intra-cluster, artinya semakin tinggi kesamaannya. Proses pengelompokan dengan SOM akan menghasilkan diagram kipas yang disajikan pada Gambar 5.

\section{Clusters}
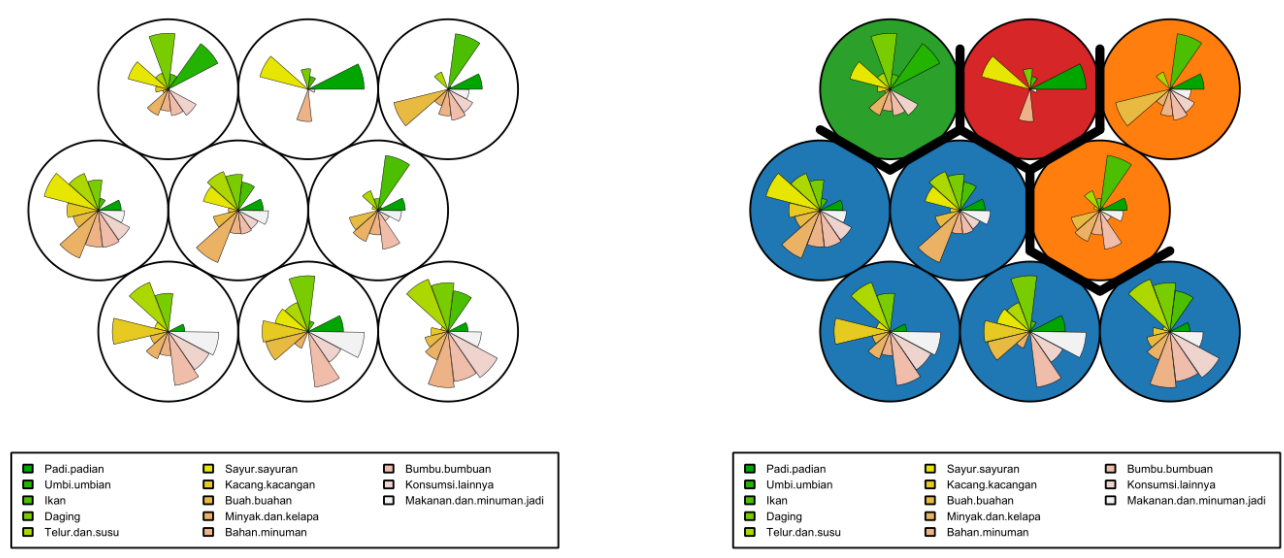

Gambar 5. Diagram kipas

Gambar 5 merupakan diagram kipas menggunakan tampilan heksagonal dengan grid berukuran $3 \times 3$. Diagram kipas menunjukkan distribusi variabel yang digunakan. Pada diagram kipas di atas terdapat 4 warna berbeda yang menunjukkan hasil cluster setiap provinsi, yang rangkumannya disajikan pada Tabel 1. Setiap warna memiliki karakteristik yang berbeda. Jika dilihat secara kasat mata, akan sulit untuk menentukan karakteristik setiap cluster karena jumlah variabel yang digunakan cukup banyak. Karakteristik cluster dapat dilihat dari nilai rata-rata setiap variabel yang menjadi anggota dari setiap cluster yang terbentuk.

Table 1. Jumlah dan anggota cluster

\begin{tabular}{|c|c|c|}
\hline Cluster & $\begin{array}{c}\text { Jumlah } \\
\text { Anggota }\end{array}$ & Anggota \\
\hline 1 & 22 & $\begin{array}{l}\text { Sumatera Utara, Sumatera Barat, Riau, Jambi, Sumatera Selatan, } \\
\text { Bengkulu, Lampung, Kep. Bangka Belitung, Kep. Riau, DKI Jakarta, } \\
\text { Jawa Barat, Jawa Tengah, DI Yogyakarta, Jawa Timur, Banten, Bali, } \\
\text { Nusa Tenggara Barat, Kalimantan Barat, Kalimantan Tengah, } \\
\text { Kalimantan Selatan, Kalimantan Timur, Kalimantan Utara }\end{array}$ \\
\hline 2 & 10 & $\begin{array}{l}\text { Aceh, Sulawesi Utara, Sulawesi Tengah, Sulawesi Selatan, Sulawesi } \\
\text { Tenggara, Gorontalo, Sulawesi Barat, Maluku, Maluku Utara, Papua } \\
\text { Barat }\end{array}$ \\
\hline 3 & 1 & Papua \\
\hline 4 & 1 & Nusa Tenggara Timur \\
\hline
\end{tabular}


Dari Tabel 1 diketahui bahwa cluster 1 terdiri dari 22 provinsi, cluster 2 terdiri dari 10 provinsi, cluster 3 terdiri dari 1 provinsi, dan cluster 4 terdiri dari 1 provinsi. Setelah itu akan dihitung rata-rata data setiap variabel yang dimiliki oleh masing-masing cluster, yang disajikan pada Tabel 2. Langkah ini dilakukan untuk mengetahui karakteristik cluster yang terbentuk.

Table 2. Profilisasi cluster

\begin{tabular}{lrrrr}
\hline \multirow{2}{*}{ Variabel } & \multicolumn{4}{c}{ Rata-rata } \\
\cline { 2 - 5 } & Cluster 1 & Cluster 2 & Cluster 3 & Cluster 4 \\
\hline Padi-padian & 819,60 & 844,24 & 579,34 & 1166,22 \\
Umbi-umbian & 30,26 & 38,21 & 472,09 & 26,60 \\
Ikan & 56,15 & 64,02 & 50,95 & 49,14 \\
Daging & 74,76 & 62,19 & 90,97 & 49,77 \\
Telur dan susu & 64,12 & 57,57 & 40,73 & 27,32 \\
Sayur-sayuran & 40,51 & 38,30 & 47,37 & 50,45 \\
Kacang-kacangan & 46,06 & 40,69 & 35,59 & 28,30 \\
Buah-buahan & 46,66 & 51,29 & 32,56 & 28,04 \\
Minyak dan kelapa & 274,01 & 267,14 & 256,14 & 172,72 \\
Bahan minuman & 99,69 & 98,39 & 92,20 & 98,61 \\
Bumbu-bumbuan & 9,75 & 9,36 & 7,09 & 3,03 \\
Konsumsi lainnya & 55,67 & 50,69 & 47,92 & 24,64 \\
Makanan dan minuman jadi & 503,70 & 461,36 & 161,17 & 223,26 \\
\hline Total & 2120,92 & 2083,45 & 1914,12 & 1948,10 \\
\hline
\end{tabular}

Tabel 2 menunjukkan bahwa cluster 1 memiliki total rata-rata konsumsi kalori yang berasal dari komoditas padi-padian, umbi-umbian, ikan, daging, telur dan susu, kacangkacangan, buah-buahan, minyak dan kelapa, bumbu-bumbuan, konsumsi lainnya, serta makanan dan minuman jadi sebesar 2120,92 kkal. Nilai ini paling besar dibandingkan dengan cluster lainnya. Menurut Permenkes No. 75 Tahun 2013, rata-rata kecukupan kalori penduduk Indonesia per hari adalah sebesar $2150 \mathrm{kkal}$. Oleh karena itu, berdasarkan profilisasi cluster pada Tabel 2, yang memenuhi aturan tersebut hanya cluster 1 . Hal ini dapat menjadi perhatian pemerintah dalam memperhatikan konsumsi pangan di setiap wilayah cluster sehingga dapat meningkatkan standar kecukupan pangan tersebut karena konsumsi pangan yang cukup, baik kuantitas dan kualitas, akan menciptakan sumber daya manusia unggul.

\section{Kesimpulan}

Berdasarkan hasil analisis, diperoleh kesimpulan bahwa jumlah cluster optimum dalam pengelompokan wilayah Indonesai berdasarkan data konsumsi pangan adalah sejumlah 4 cluster, yang ditentukan oleh nilai Davies-Bouldin Index terkecil. Penggunaan algoritma self-organizing map menghasilkan pengelompokan wilayah dengan jumlah anggota untuk cluster 1 sebanyak 22 provinsi, cluster 2 sebanyak 10 provinsi, cluster 3 sebanyak 1 provinsi, dan cluster 4 sebanyak 1 provinsi. Hasil pengelompokan wilayah menyatakan bahwa provinsi-provinsi pada cluster 2, cluster 3, dan cluster 4 masih memiliki rata-rata kecukupan kalori penduduk di bawah standar Permenkes No. 75 Tahun 2013. 
Self-Organizing Map Menggunakan Davies-Bouldin Index dalam Pengelompokan ...

Referensi

[1] Kemenkeu, “3 Fokus Kebijakan Pembangunan Pembangunan Indonesia di Masa Mendatang," Publikasi Kementerian Keuangan Republik Indonesia, Jakarta, 2020.

[2] K. von Grebmer et al., 2020 Global hunger index: One decade to zero hunger, linking health and sustainable food systems. Dublin: Welthungerhilfe \& Concern Worldwide, 2020.

[3] Kemenpan, Kebijakan Strategis Ketahanan Pangan dan Gizi 2020-2024. Jakarta: Badan Ketahanan Pangan Kementerian Pertanian, 2019.

[4] J. Han, M. Kamber, and J. Pei, Data Mining Consepts and Techniques Third Edition. United States of America: ELSEVIER, 2012.

[5] R. Xu and D. C. Wunsch, Clustering. New Jersey: John Wiley \& Sons, Inc., 2009.

[6] L. Yang, Z. Ouyang, and Y. Shi, "A modified clustering method based on selforganizing maps and its applications," Procedia Comput. Sci., vol. 9, pp. 1371-1379, 2012, doi: 10.1016/j.procs.2012.04.151.

[7] T. Kohonen, “The Self-Organizing Map," Proc. IEEE, vol. 78, no. 9, pp. 1464-1480, 1990, doi: 10.1109/5.58325.

[8] Y. Li et al., "Land use pattern, irrigation, and fertilization effects of rice-wheat rotation on water quality of ponds by using self-organizing map in agricultural watersheds," Agric. Ecosyst. Environ., vol. 272, no. November 2018, pp. 155-164, 2019, doi: 10.1016/j.agee.2018.11.021.

[9] V. J. A. S. Lobo, "Application of self-organizing maps to the maritime environment," Lect. Notes Geoinf. Cartogr., no. June, pp. 19-36, 2009, doi: 10.1007/978-3-642-00304-2_2.

[10] P. Potočnik et al., "SOM-Based Clustering and Optimization of Production," 2017.

[11] P. Juntunen, M. Liukkonen, M. Lehtola, and Y. Hiltunen, "Cluster analysis by selforganizing maps: An application to the modelling of water quality in a treatment process," Appl. Soft Comput. J., vol. 13, no. 7, pp. 3191-3196, 2013, doi: 10.1016/j.asoc.2013.01.027.

[12] P. Zeng, F. Sun, Y. Liu, Y. Wang, G. Li, and Y. Che, "Mapping future droughts under global warming across China: A combined multi-timescale meteorological drought index and SOM-Kmeans approach," Weather Clim. Extrem., vol. 31, p. 100304, 2021, doi: 10.1016/j.wace.2021.100304.

[13] P. Melin, J. C. Monica, D. Sanchez, and O. Castillo, "Analysis of Spatial Spread Relationships of Coronavirus (COVID-19) Pandemic in the World using Self Organizing Maps," Chaos, Solitons and Fractals, vol. 138, p. 109917, 2020, doi: 10.1016/j.chaos.2020.109917.

[14] S. M. Guthikonda, Kohonen Self-Organizing Maps. Wittenberg University, 2005.

[15] D. L. Davies and D. W. Bouldin, "A Cluster Separation Measure," IEEE Trans. Pattern Anal. Mach. Intell., vol. 1, no. 2A, 1979, doi: https:// doi.org/10.1109/TPAMI.1979.4766909.

[16] T. Kohonen, "Self-Organized Formation of Topologically Correct Feature Maps," Biol. Cybern., vol. 43, pp. 59-69, 1982. 
[17] U. Asan and E. Secil, “An Introduction to Self-Organizing Maps,” Atlantis Press Book, 2012.

[18] D. T. Larose and C. D. Larose, Discovering Knowledge in Data: An Introduction to Data Mining Second Edition. United States of America: John Wiley \& Sons, Inc, 2014.

[19] BPS, Konsumsi Kalori dan Protein Penduduk Indonesia dan Provinsi Berdasarkan Hasil Susenas Maret 2020. Jakarta: Badan Pusat Statistik, 2020.

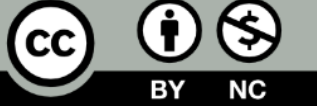

This article is an open-access article distributed under the terms and conditions of the Creative Commons Attribution-NonCommercial 4.0 International License. Editorial of JoM: Department of Mathematics, Universitas Negeri Gorontalo, Jln. Prof. Dr. Ing. B.J. Habibie, Moutong, Tilongkabila, Kabupaten Bone Bolango, Provinsi Gorontalo 96119, Indonesia. 